\title{
Financial Inclusion and Access to Higher Education An Empirical Study of Selected Districts in Eastern Uganda
}

\author{
Dr. Marus Eton ${ }^{1} \quad$ Dr. Sammy Godfrey Poro ${ }^{2} \quad$ Dr. Denis Sekiwu ${ }^{1} \quad$ Fabian Mwosi $^{3}$ \\ Dr. Francis Akena Adyanga ${ }^{1}$ \\ 1.Kabale University-Kabale Uganda \\ 2. UNICEF-Uganda \\ 3.Bishop Barham University College-Kabale Uganda
}

\begin{abstract}
Access to higher education has continuously been a challenge in Uganda. The research brought out the relationship between financial inclusion and access to higher education. Descriptive survey research design was adopted and the findings established that digital financing eases making deposits in banks, transacting via mobile money and switching from one bank to the other. Students find it easy to deposit tuition in the bank just as they find it easy to access money via mobile money. While financial inclusion makes financial services available in the economy, students, especially those from low-income families find difficulty accessing a wider range of these products, which hinders their access to higher education. The study also establishes that a good number of students fail to meet admission requirements. Since students from low-income families attend high schools of low quality, they have insufficient understanding of some subjects, and thus unable to join higher education. Online registration and payment, students' decision not to join, peer influence, and rigidity of university programs; are deeply flawed to limit accessing higher education. However, financial services remain accessible to rich individuals who demonstrate ability to pay. The study recommends that the government of Uganda through the concerned ministry should review the implementation of their policies on Students loan scheme and district quota systems. The government should always publish the lists of students admitted to higher education institutions in popular media and newspapers to create awareness to those being admitted to particular institutions.
\end{abstract}

Keywords: Financial Inclusion. Digital Financing, Financial Services, Access to Higher Education, Higher Education Financing

DOI: $10.7176 / \mathrm{EJBM} / 12-17-10$

Publication date:June 30th 2020

\section{Introduction}

Financial Inclusion broadly refers to the degree of access to financial services by households and firms. The World Bank (2014) defines Financial Inclusion (FI) as the proportion of individuals and firms that use financial services. The problem of access to financial services among the poorest sectors of the population is not something new. World Bank (2013) observes that FI is crucial as access to financial services is frequently measured as an operative instrument that can aid the decrease in income inequality. Similarly, FI is one way by which we promote the objective of inclusive growth through the provision of easy access to financial services among the most disadvantaged sections of society. Financial Inclusion is recognized as an important component in the drive to increase prosperity across developing countries (Messy and Monticone, 2012), and these can provide valuable impetus in developing policy responses. Eton et al..., (2019) reveals that FI is significant as it supports economic growth, upholds equitable distribution of growth benefits, transforms people's way of living and empowers people to go for financial services that are germane to their needs, thus enhancing capital creation.

Higher education refers to post-secondary school education in institutions that include traditional Universities and Universities of Technology (DHET, 2013a). In Uganda, "higher education" denotes education at university and other tertiary institution level. For the purpose of this study, the term higher education refers to all postsecondary school studies, training and research at educational institutions that are authorized as institutions of higher education by the regulatory authorities. The institutions of higher learning offer courses designed to award successful students with certificates, diplomas, degrees and postgraduate qualifications (Haus, 2006). The major challenges governments' world over face is how to reform the financing of higher education to meet the pressures arising out of private demand for admission to higher education and financing of heavy budgets. Governments have grappled with the problem of rapidly increasing public expenditure on higher education yet financing of higher education is declining. Higher education in Africa and in Uganda in particular, has a significant role to play in development - including the attainment of sustainable development goals (SDGs). Higher education financing has been at the forefront of higher education debates for decades, especially in developing countries (UNESCO, 2011). Much as higher education services may be private investment, it has other externalities that are positive, and thus makes sense for a government to pay for this social contribution that educated individuals like engineers, doctors, teachers and others make to society (Hull, 2015).

The Government of Uganda wants to ensure equitable access to higher education by Ugandans, which the 
majority of the qualifying post-secondary school students cannot afford; and ensure regional balance for disadvantaged areas and support programmes which are critical for social, economic and technological development of the country (HESFB, 2014). The Uganda Government has a policy of extending higher education to all regions by establishing, and/or by encouraging establishment of, new universities and other higher institutions of learning in the country. Eastern Uganda has been a beneficiary of this policy in order to improve access to higher education.

\section{Problem statement}

It is common for government authorities to be mandated to address financial inclusion. Although higher education has expanded, the absolute prospects of poorer students to invest in further studies are seen to have little impact on their relative prospects. While only $20 \%$ of the world population aged twenty-five (25) and above has completed a tertiary institution, many efforts had been made to increase the enrollment rate which rose in 2018 from $12 \%$ in the early 1990's (UNESCO, 2017). The higher education sector is not able to meet the growing demand for higher education by all sections of society. The growth in enrolment in higher education in Uganda has placed a strain on public higher education institutions, with financial resources allocated to public institutions not growing at the same pace as enrolment. Ekanya (2018) observes that the dropout rates of students from higher education in eastern Uganda from 2015 to 2018 were at $70 \%$, which was high that needed for address.

Johnston (2010) observes that a long queue of crucial needs that compete with public higher education for share of the scarce public revenues had been increasing the financial pressure on higher education, especially in low and middle-income countries. Pillay ,2010) points out that some sections of the citizens cannot access admission to tertiary education due to stringent admission criteria's set by different educational institutions; this therefore prevents access to higher education. Adongo (2010) observes that financing of higher education is not clear and as a result, there are frequently large gaps between institutional demand for funds and actual fund allocation. There are many financial institutions which offer education loans that can be accessed by individuals so long as they can be pay back. Uganda government has brought a policy for higher education financing where those who qualify should apply using the normal procedure and you pay back after completion of your study. Despite the critical role of education, the relationship between financial inclusion and access to higher education in Uganda has not been accorded deserving consideration. Establishing such a relationship is essential for policy makers given the low level of financial inclusion in Uganda and the potential for FI to foster quicker achievement of the sustainable development goals.

\section{Objectives of the study}

To examine the role of digital financing in supporting access to higher education

To establish the challenges faced by learners in accessing higher education

To determine the relationship between financial inclusion and access to higher education

\section{Literature Review}

\section{Financial Inclusion}

Atkinson and Messy(2013) define financial inclusion as the process of promoting affordable, timely, and adequate access to a wide range of regulated financial products and services. This include broadening their use by all segments of society through implementing existing tailored and innovative approaches including financial awareness and education with a view to promote financial well-being as well as economic and social inclusion. Morgan and Pontines, (2014), notes that FI may contribute to financial stability and thereby decrease the risk of bank assets and foster a stable funding base of bank deposits. Yoshino and Morgan, (2016) observes that greater FI assists the marginalized sections of society such as the low-income groups, rural people, the youth and females. Menon et al...., (2011) argues that greater access to formal credit services can augment self-employment and thus reduce the extent of unemployment and underemployment. In order to give marginalized groups access to financial services, an efficient financial system, which is inclusive, should be put in place. Eton et al...l,(2019) observes that access to formal financial services would enable citizens start personal businesses, which will increase financial inclusion. Chithra and Selvam, (2013) affirms that factors like educational attainment, income level, household characteristics and occupational factors are possible determinants of FI. Allenet al..,(2016) observes that women, the poor and those living in rural areas tend to be financially excluded. This could be due to the limited availability of financial products and services in the rural areas. Demirguc-kunt and Klapper, (2012) argues that lack of money, trust, limited knowledge of financial products and high cost, and distance to access points are some of the causes of financial exclusion.

The development of e-money can make a substantial contribution to reducing the cost and inconveniences accruing from making payments. Digital financial inclusion helps banks lower costs through reduction of queues in banking halls, manual paperwork and documentation, and maintenance of fewer bank branches (IFC, 2017). With digital financial inclusion, a large number of depositors can easily switch banks within minutes forcing banks 
to provide quality services or risk losing depositors to rival banks. Llanto, (2015) argues that e-money accounts and e-money transactions grow significantly in the past few years. This could be because the world has accepted and supported the growth of information technology in the recent decades. Kelegama and Tilakaratna, (2014) establishes that commercial banks have introduced e-remittance services to capture large-scale inward remittance flows although it is difficult to measure their penetration into the market. CGAP, (2015) notes the three key components of any digital financial service which include but not limited to a digital transactional platform, retail agents and use by customers and agents of a device most commonly a mobile phone to transact via the digital platform. Michelle, (2016) notes that a digital financial service is vital to the public as it boosts security for their cash, and it is more convenient compared to keeping money at home or travelling with it. Different players will be involved into this transaction, which includes regulators, financial institutions, technology, mobile network operators and other players. Radcliffe and Voorhies, (2012) observes that digital finances create better platforms which would link most people to service providers of insurance, credit and serving institutions. The usage of technology in transfer of finances has provided easy access to payment services by a larger audience, which has in turn affected individual welfare.

G20 Summit (2013) observes that notwithstanding its benefits, digital finance and financial inclusion have not adequately permeated vast segments of the population, which suggests an existing gap between the availability of finance, its accessibility and use. Manyika et al..., (2016) argues that digital finance also benefits governments by providing a platform to facilitate increase in aggregate expenditure, which subsequently generates higher tax revenue arising from increase in the volume of financial transactions. However, Dupasetal, (2016) observes that providing only basic bank accounts does not result in significantly higher savings or other downstream outcomes. InterMedia Uganda (2014) found out that nearly 40\% of Ugandan adults were financially included, and Mobile Money Services (MMS) predominantly facilitate inclusion where 33\% of the registered bank users had a mobile money account. Oluwatayo, (2013) argues that the developments in the Mobile Money Services (MMS) have helped solve infrastructural gaps that would hinder an all-financial inclusive system.ITU(2016) argues that despite the benefits of digital financial services, many countries in the developing world still face considerable challenges in attaining merchant acceptance of digital payments. Eton et al ..., (2018) argues that financial service providers should lower the cost of operating accounts for financial inclusiveness, particularly those from rural areas.

\section{Higher Education}

Oduro-Mensa (2012) defines education as a process of enhancing the knowledge; skills and positive attitude in an individual or people to enable them identify with societal aspirations and contribute towards the improvement in the quality of life in the society. Higher education refers to post-secondary school education attained at institutions that include traditional Universities and Universities of technology (DHET, 2013a). The growth of higher education in Uganda should focus on expanding opportunities available for students to include relevant vocational occupations in their region. These opportunities include expanding education to become interdisciplinary while improving the current learning environments to help motivate students. The access to higher education is further questioned due to the prevailing state of infrastructures and environment among others. Boitand and Kipkoech, (2012) reveals that students are not well motivated and not facilitated to access higher education and thus do not grow professionally. Access to higher education could be caused by poor study habits, high expectations by parents and communities, insufficient understanding of some subjects and fear of failure to access a good job (Rehman, 2016). Some students fail to access higher education because they do not meet the admission requirements to join the higher education Department of Basic Education (DBE, 2014). Uganda National Council of Higher Education guidelines and policy frame work (NCHE, 2010) has set the minimum entry requirement for university entry in Uganda to two principle pass at the Advance level examination at the same sitting, this limits those with one principle pass thus limiting access to higher education.

Zwick and Himelfarb, (2011) observes that some admission procedures such as standardized test (aptitude test) especially those given to Advance level as a requirement for joining certain Universities and University programs have consistently disadvantaged some student to access higher education. Nshemereirwe, (2016) also observes that Uganda Universities played a role by maintaining selection procedures that favored students from higher socioeconomic status while those from lower economic status are disadvantaged. Although political decision was taken that led to the introduction of district quota system for admission to public universities in order to take care of regional balance in university admission and cater for the disadvantaged families. Tinkamanyire, (2010) notes that the government policy on science education has made some science subject compulsory at secondary schools but not taking into consideration that most students are note good in science. WambogaMugirya, (2005) also observes that government decreed that science subjects would receive $75 \%$ of the government scholarships to public universities and tertiary institutions. This policy was discriminatory since it does not support equity and inclusive education because other students are disadvantaged from studying what they would prefer to study. Jerrim and Vignoles, (2015) establishes that inequality in access to higher education in developing countries is due to inequalities in attainment in primary and secondary schooling. Wedekind, (2013) 
in his study found out that some school leavers who had a national senior certificate with good grades were not well prepared for higher education studies. Kim et al..,(2010) points out non-academic factors that may influence a student's decision not to join higher education - these may include attitude, motivation, confidence and selfefficiency with critical thinking and decision making. In their study,(Trautwein \& Bosse, (2016) found out that some relationships with peers could be detrimental to progressing to higher education. Some peers may give wrong advice that may lead to dropping out. Ssegawa,(2012) observes that the liberalization of higher education enabled the entry into university education of proprietors that are incapable of meeting university quality, let alone introduction of modes to accessing university education in which accessibility to higher education is not satisfactory. Masanja and Lwakabamba, (2016) establishes that private providers and cross-border providers have focused on business. They provide poor quality education. They target programmes, which are lucrative for their business prospects rather than those with the priority for the socio-economic development of their countries, and they do not conduct research, innovation and professional development of their staff. Devarajan et al..., (2011) notes that higher education in Africa suffers from institutional rigidities that make it difficult for colleges and universities to adjust accordingly and develop strategies that make them more responsive to the changes in the global and labour market demand. McCole et al..., (2014) establishes that sustaining programmes created to bring about change are some of the most challenging obstacles universities would face after implementation. The lack of sustainability could be caused by high labour turnover caused by poor conditions at the universities (Blackie et al..., 2010). The curriculum should be designed to be consistent and explicit on how to assist students transition from their previous educational experience to the nature of learning in higher education institutions (Smith, 2010). Accordingly, Van der Berg et al...., (2017) observes that financial constraints are limiting university access for many of the learners especially from socially economic constrained families. Roble, (2017) argues that financial challenges area factor that affects transition from high schools to higher education institutions. Students from lowincome families may have to manage difficult financial choices. The relative low levels of government spending on tertiary education and relatively low quality of education at lower levels of education affect enrollment rates into higher education. However, Hong and Chae, (2011) argues that access to higher education in many countries has been supported by the implementation of student loan schemes as a means of sharing the costs involved in the expansion of higher education. OECD (2015) observed that most universities have adopted the usage of information and communication technology. This has prompted the introduction of online payment, on line registration, which has been a hindrance to access to other information, which makes it a challenge for potential learners to join such institution since most learners do not know how to work with the system; they fail to access university education.UIS (2014) observes that since the mid-1990s, universities in several African countries had seen profound funding reorganization, which introduced elements of private funding. The policy of cost sharing has been accepted and adopted by many countries in both the developed and the under-developed world. The average annual allocation to the public universities for recurrent expenditure is very little. The National Council for Higher Education in Uganda (NCHE, 2013) reports that modest funds had been channeled through the NCHE for research and staff training in public universities. Of this allocation, $0.82 \%$ was to be used for research(NCHE, 2013).Countries which have an expanded system of higher education with higher levels of investment in research and development (R\&D) activities have a higher potential to grow faster in a globalized knowledge economy (Varghese, 2013).

\section{Financial Inclusion and Higher Education}

Higher education is no longer isolated from the larger society and especially not from the economy. Its funding is no longer guaranteed, and its social missions are under public scrutiny. Yizengaw, (2008) argues that inadequate finance could be due to poor economic conditions, competing public service priorities and weak support from international community has led to poor government financing on infrastructural development and ability to retain staff and research funding in higher education. Pfeffermann, (2015) argues that there has been increasing competition for public funds together with tight budgets; it is noted that public sector funding is not adequate to meet the increased demand for higher education, often compromising on quality. Tobyehatch, (2013) observes that there are ever-rising costs of education overtime to the extent that it outpaces the demands of the consumer. Tilak, (2011) establishes that governments had been the main financiers of higher education in many countries around the world. However, throughout the years there has been a considerable decrease in aggregate government spending on higher education. McMahon, (2009) points out that the problem is that, although families and students are conversant with the increases in earning, a purely market benefit associated with acquiring higher education, they are often very vaguely aware of the value of non-market benefits beyond earnings that enhance the quality of life. Anamuah-Mensah, (2014) argues that investments in skills and knowledge of the people promote development. Similarly, Zins and Weills, (2016) observes that being a man, richer, more educated and older, favours financial inclusion in Africa with a higher influence on education and income. Bruhn and Love, (2014) also observe that with greater financial inclusion, individuals who were previously financially excluded will be able to invest in education, save and launch businesses, and this contributes to economic growth. 
Espinosa et al..., (2019) establishes that post-secondary education is a path to economic security, given the workforce demand for these credentials and a force for social good. Governments have left market access principles to infiltrate and influence the provision of higher education. UNESCO, (2011) reveals that it has been difficult for governments as well as the private sector to adequately finance higher education even when their efforts are combined. Mechanisms such as students financial support schemes have assisted in promoting access to higher education and fairness while sharing expenses of higher education between the state and students (OECD, 2015). However, Kyaligonza (2017) argues that the guidelines and criteria for granting loans to students should be improved to include the assessment of the economic status of applicants for study loan scheme because the economic status will determine their ability to pay back the loans. Salmi and Bassett, (2014) observes that equity promotion policies would increase opportunities for disadvantaged students and those that combine financial assistance with measures to overcome non-financial obstacles. Awanet al..., (2011) in their study notes that educational enrollment was negatively related to poverty. Hanushek and Wobman, (2007) observes that educational enrollment has not always led to expected socio-economic returns; this is because schooling is not the same as learning (World Bank, 2018a). The disparity in higher education enrolment rates between students from high-income families and their less privileged counterparts is considerable; enrollees from less privileged income groups are two times less likely to enter an elite university compared to enrollees from high-income families (Khavenson and Chirkina, 2018).

\section{Methodology}

The study used descriptive survey research design. Orondo(2009) states that sample survey consider selecting subsets of a given population which is measured over time. The survey design is more suitable because it helps in the description of the nature of the prevailing situations, provided the best standards of comparing and determining the relationship which exist amongst the variables. A structured questionnaire was developed using a 5-point Likert scale. Both purposive and simple random sampling techniques were used. A target population of 360 were chosen for the study and sample of 186 respondents participated in the study. Krejcie and Morgan table 1970 was used to determine the sample size. The study was conducted from the selected three (3) districts in eastern Uganda, which included Soroti (68),Mbale (62) and Tororo (56)respectively. The choice of the districts was based on the premise that these districts had registered lower access rate to higher education (UBOS, 2018). Descriptive statistical techniques were used to portray the role of digital financing in supporting access to higher education, and the challenges learners encounter in accessing higher education. Correlation analysis was adopted to test for the relationship between digital financing and access to higher education.

\section{Results}

The findings of the study are based on 166 respondents out of the expected sample size of 186 study subjects. This translates into a response rate of $89.2 \%$, which is far above the acceptable response rate of $70 \%$. The researcher presented participants' demographic characteristics and empirical results based on research objectives.

Table 1: Demographic characteristics

\begin{tabular}{llcc}
\hline \hline Variable List & Categories & Frequency & Valid Percent \\
\hline Gender & Male & 98 & 59 \\
& Female & 68 & 41 \\
& Total & 166 & 100 \\
\hline Age & $18-22$ & 112 & 67.5 \\
& $23-27$ & 30 & 18.1 \\
& $28-32$ & 14 & 8.4 \\
& Over 32 & 10 & 6 \\
\hline Home district & Total & 166 & 100 \\
\hline Parent's education & Mbale & 55 & 33.1 \\
& Soroti & 62 & 37.3 \\
& Tororo & 49 & 29.5 \\
& Total & 166 & 100 \\
\hline
\end{tabular}




\begin{tabular}{llcc}
\hline \hline Variable List & Categories & Frequency & Valid Percent \\
\hline School status & Yes & 129 & 77.7 \\
& No & 37 & 22.3 \\
& Total & 166 & 100 \\
\hline Institution or University & University & 47 & 36.4 \\
& Institution & 82 & 63.6 \\
& Total & 129 & 100 \\
Missing & 9 & 37 & \\
Total & & 166 & \\
\hline \hline
\end{tabular}

\section{Source: field data, 2020}

The gender participation indicates that 98 (59\%) were male while $68(41 \%)$ were female. Certainly, the variation in gender suggests the gender disparity that exists in access to post secondary education in Uganda. Most of the participants $(67.5 \%)$ belonged to $18-22$ years of age, portraying the average age at which students in Uganda complete senior six. Those who were over 22 years of age suggest those who completed senior six when they are old or those who had stayed out of school after senior six. The researcher purposively determined the variation in participation according to home district with most participants obtained from Soroti (37.3\%) followed by Mbale (33.1\%) and then Tororo (29.5\%). Reports on parents' education indicate that $128(77.7 \%)$ of the participants' had attained above secondary education. This suggests that such parents are informed enough to encourage their children join higher education. The study established that $129(77.7 \%)$ were studying while 37 $(22.3 \%)$ were not studying. Of those who were studying, 47 (36.4\%) were university students while $82(63.6 \%)$ were students in other institutions of higher learning.

\section{Objective one: To examine the role of digital financing in supporting access to higher education} Table 2: Digital Financing

\begin{tabular}{|c|c|c|c|c|c|}
\hline Variable List $(\mathrm{N}=166)$ & $\begin{array}{l}\text { Disagreeme } \\
\text { nt }(\%)\end{array}$ & $\begin{array}{l}\text { Not Sure } \\
\qquad(\%)\end{array}$ & $\begin{array}{c}\text { Agree } \\
\text { ment } \\
(\%)\end{array}$ & Mean & Std. \\
\hline 1. I find it easy to make deposits in the bank & 0 & & 100 & 4.825 & 0.381 \\
\hline 2. I have a mobile money account & 0.6 & 1.2 & 98.2 & 4.633 & 0.575 \\
\hline $\begin{array}{l}\text { 3. Digital financing helps students from poor families } \\
\text { to access higher education }\end{array}$ & 16.3 & 5.4 & 78.3 & 3.958 & 1.041 \\
\hline 4. I find it easy making transactions via mobile money & 15.7 & 19.9 & 64.4 & 3.765 & 1.078 \\
\hline 5. I find it easy switching from one bank to another & 15 & 18.7 & 66.3 & 3.645 & 1.079 \\
\hline 6. I have access to financial services & 40.3 & 16.3 & 43.4 & 2.837 & 1.566 \\
\hline $\begin{array}{l}\text { 7. Transacting on phone is cheaper than lining in the } \\
\text { bank }\end{array}$ & 57.3 & 8.4 & 34.3 & 2.416 & 1.470 \\
\hline 8. I have access to a digital transactional platform & 55.4 & 11.4 & 33.1 & 2.410 & 1.542 \\
\hline 9. My phone is useful in transacting with my bank & 58.4 & 12 & 29.5 & 2.325 & 1.449 \\
\hline 10. I have access to a wider range of financial products & 60.2 & 14.5 & 25.3 & 2.205 & 1.416 \\
\hline
\end{tabular}

\section{Source: Field data, 2020}

Examining if digital financing has a role to play in accessing higher education, all the participants (100\%) confirmed that digital financing makes depositing in banks easy. This relates to ease of paying both tuition and functional fees. Of those who took part in the study, 98.2\%confirmed having mobile money accounts, which in practical terms, are important in accessing tuition balances from parents, especially of the poor children. Students from poor families do not complete their tuition at once, and therefore need to collect some from home, which is effected via mobile money. Based on the findings, $78.3 \%$ believe digital financing might help students from poor families to access higher education. Practically, digitalizing banking operations simplifies transacting with banks, especially to students. Students from poor families finance higher education via their mobile money accounts. Participants disagreed with the claims on having access to a wider range of financial products $(60.2 \%)$, transacting with their banks via mobile phones $(58.4 \%)$, finding it cheaper to transact on mobile phones than lining up in banking hall $(57.3 \%)$, and having access to digital transactional platform (55.4\%). The findings suggest though many students appear to have mobile money accounts, they are not confident enough to use them for paying university and institutional tuition and functional fees.

The standard deviations indicate consistency in interpreting and understanding the researcher's claims on making deposits in banks (Std. $=.381)$ and owning mobile money accounts $($ Std. $=.575)$. The statistics suggest that participants are familiar with banking operations, especially making deposits, and have mobile money accounts. 
The familiarization with making deposits in banks draws from their experiences at high school level where school fees were banked while having mobile money accounts draws from the government's drive towards financial inclusion. However, participants appeared to present inconsistent opinions on having access to financial services $($ Std. $=1.566)$ and having access to digital transactional platforms $($ Std. $=1.542)$. The divergence in opinions suggests differences in sponsorship to those who 'are sponsored' and those who are 'not sponsored'. Of certainty, participants who were studying under some sponsorship, especially government could have interpreted having access to financial services while those who were studying under 'private sponsorship' and those who were 'not studying' could have interpreted the same claim inversely. Similarly, the participants who interpreted having access to digital transaction platform were in universities and institutions in which students compulsorily have these platforms. Otherwise, those who are not in school and those who study in institutions and universities where digital transaction platforms are not compulsory could have interpreted the same claim inversely.

Objective two: To establish the challenges faced by learners in accessing higher education Table 3: Access to higher education

\begin{tabular}{|c|c|c|c|c|c|}
\hline Variable List $(\mathrm{N}=166)$ & $\begin{array}{l}\text { Disagreement } \\
(\%)\end{array}$ & $\begin{array}{l}\text { Not Sure } \\
\quad(\%)\end{array}$ & $\begin{array}{c}\text { Agree } \\
\text { ment } \\
(\%)\end{array}$ & Mean & Std. \\
\hline 1. Failure to meet admission requirements & 0 & 0 & 100 & 4.886 & 0.319 \\
\hline 2. Coming from low income families & 3 & 0 & 100 & 4.795 & 0.405 \\
\hline 3. Insufficient understanding of some subjects & 2.4 & 0 & 96.4 & 4.711 & 0.679 \\
\hline $\begin{array}{l}\text { 4. Government policy on compulsory science } \\
\text { subjects }\end{array}$ & 2.4 & 2.4 & 95.2 & 4.572 & 0.690 \\
\hline 5. Poor study habits & 5.4 & 1.2 & 96.3 & 4.536 & 0.675 \\
\hline $\begin{array}{l}\text { 6. Private providers of higher education are } \\
\text { business focused }\end{array}$ & 17.5 & 15.7 & 75.3 & 3.964 & 1.038 \\
\hline $\begin{array}{l}\text { 7. Inequalities in attainment of primary } \\
\text { education }\end{array}$ & 21.7 & 15.7 & 67.4 & 3.789 & 1.138 \\
\hline 8. Regional imbalance in university admission & 16.9 & 12.7 & 66.9 & 3.645 & 1.073 \\
\hline 9. Unpreparedness for higher education studies & 12.6 & 19.3 & 60.8 & 3.590 & 1.155 \\
\hline 10. Infrastructure & 26.5 & 18.1 & 58.5 & 3.380 & 1.324 \\
\hline 11. Fear of failure of access to a good job & 31.4 & 9.6 & 62.7 & 3.349 & 1.357 \\
\hline $\begin{array}{l}\text { 12. High expectation by parents and } \\
\text { communities }\end{array}$ & 47 & 16.3 & 52.4 & 3.199 & 1.349 \\
\hline 13. Self- motivation & 30.8 & 14.5 & 41 & 2.982 & 1.351 \\
\hline $\begin{array}{l}\text { 14. Failure of universities to adjust to market } \\
\text { demand }\end{array}$ & 34.9 & 8.4 & 49.4 & 2.964 & 1.481 \\
\hline 15. Peer influence & 38.5 & 12.7 & 46.4 & 2.928 & 1.567 \\
\hline 16. Students' decision not to join & 65.6 & 9.6 & 25.3 & 2.096 & 1.457 \\
\hline 17. Online payments and registration & 75.9 & 4.8 & 12.6 & 1.602 & 1.210 \\
\hline
\end{tabular}

\section{Source: Field data, 2020}

In view of the challenges to accessing higher education, majority of the participants pointed to failure to meet admission requirements, and coming from low income families (100\%); insufficient understanding of some subjects $(96.4 \%$ ), poor study habits $95.2 \%$, and government policy on the compulsory subjects $(95.2 \%)$. A critical look at these barriers suggests that gaps in Uganda's policies that can enhance access to higher education. For instance, joining the university or other tertiary institutions is purely a factor of admission requirements, which leave out many students from getting admissions. Participants disagreed with the claims on online payments and registration $(75.9 \%)$, students' decision not join $(65.6 \%)$ and high expectations from parents and communities $(47.0 \%)$. In practical terms, no student can fail to join the university just because that he/she cannot stand up the requirement for online registration and payments. These institutional issues can be handled via orientation programs once the student has joined. The grounds upon which students can deliberately refuse to join higher education are indeed existent such decisions are not properly grounded in academic research.

Participants presented consistency in opinion on some of the challenges to accessing higher education in Uganda. For instance, failure to meet admission requirements (Std. =.319), coming from low-income families (Std. $=.405)$, insufficient understanding of some subjects $(\mathrm{Std} .=.679)$, government policy on compulsory subjects (Std. $=.690)$ and poor study habits $(\mathrm{Std} .=.675)$. The factors on which participants deliberated on consistently are very plain in Uganda's education. The consistence also suggests that the claims, as raised by the researcher were interpreted and understood clearly. Finally, the measure of central tendency used (mean) provided a clear portrayal of the challenges that indeed prove barrier to accessing higher education. Participants appeared inconsistent in their opinion on peer influence $(\mathrm{Std} .=1.567)$, rigidity in universities to adjust to market demands $($ Std. $=1.481)$ 
and students' decision not to join $($ Std. $=1.457)$, as barriers to accessing higher education. Peer influence and students' decision not to join might be a hindrance to students from rich-income families whose backgrounds are stable and children see little need for higher education. However, among low-income families, peer influence lacks much support.

Objective three: To determine the relationship between financial inclusion and access to higher education The study employed correlational tests to bring out the relationship between financial inclusion and access to higher education. Correlation is the statistical measure of the degree of strength of the relationship between numerical variables, measured by the correlational coefficient. Correlation coefficients closer to 0.0 mean 'weak associations' while those closer to 1.0 mean 'stronger associations'.

Table 4: Correlational tests

\begin{tabular}{llcc}
\hline \hline Variable List & & Digital Financing & Access to Higher Education \\
\hline Digital Financing & Pearson Correlation & 1 & \\
& Sig. (2-tailed) & & \\
& $\mathrm{N}$ & 166 & \\
Access to Higher Education & Pearson Correlation & $.422(* *)$ & 1 \\
& Sig. (2-tailed) & .000 & 166 \\
& $\mathrm{~N}$ & 166 & 166 \\
\hline \hline
\end{tabular}

** Correlation is significant at the 0.01 level (2-tailed).

From the table above, $(\mathrm{r}=.422)$ indicates a moderate association between financial inclusion and access to higher education. Statistically, the correlation means that a variation in financial inclusion, such as digital financing is associated to a moderate variation in the number of students who can access higher education in eastern Uganda. Significant value (sig. $=.000$ ) further reveals that there exists a linear relationship between financial inclusion and access to higher education. In practical terms, as more students gain access to financial services, a moderate number is likely to join universities and institutions of higher learning.

\section{Discussion}

One of the objectives of the study was to examine the role of digital financing in supporting access to higher education. The study established that digital financing is useful in helping students make deposits in banks, especially via mobile money, easily access higher education, and switching from one bank to another. Students find it easy to deposit tuition and functional fees in banks. Since different banks share common banking platforms, a student owning an account in one bank can easily access their accounts by switching through banks with shared platforms. The findings support (IFC, 2017) that reports digital financial inclusion helps banks lower costs by reducing queues in banking hall, reduce paper work and documentation and maintaining fewer branches. While the reduction in costs is more pronounced on the banker, it presents related benefits to students. Since digital financing involves less paper work, students, find it easy to make transactions with different banks on digital platforms. The findings support (Michelle, 2016) who notes that digital financial services boost the security of money especially on travel. The aspect of security of cash is very essential to students who are new to banking services. Rather than travelling with money in cash where they are highly vulnerable to squanders, money-grubbers, money-launderers, conmen and fraudsters; digital financial services reduce the risks of travelling with physical cash. The findings however, disagree with (Radcliffe \&Voorhies, 2012; Manyika, et al..., 2016) who indicates that digital finances create platforms which link most people to service providers of insurance, credit and serving institutions. The study established that most students lack digital transactional platforms, which might limit their access to higher education, as they cannot meet the requirements needed to gain access to some of the services provided in universities and colleges.

The findings also disagree with (Oluwatayo, 2013) on how mobile money services solve infrastructural gaps that hinder financial inclusive systems. While mobile money helps students from poor families to access tuition balances from their parents, the study establishes that making transactions on mobile phones is expensive compared to lining up in banking halls. This view agrees (Eton, et al..., 2018; Inter Media Uganda, 2014; ITU, 2016) who report different drawbacks on mobile money and financial inclusion. Honestly, mobile money services in Uganda are expensive, and far expensive for use to students from poor families. A related drawback to digital financing relates to a lack of confidence among students on transacting with banks via mobile phones. This lack of confidence opens students from poor families to fraudsters who might surface in the name of offering help. A number of university students have fallen prey to fraudsters in the guise of offering help on digital transactions.

The second objective of the study was to establish the challenges faced by learners in accessing higher education. The study points to failure to meet university requirements and coming from low-income families. The findings are consistent with (DBE, 2014) who reports that students fail to access higher education for failure to meet the requirements set by the National council for higher Education. In most cases, students from poor families are unable to meet such requirements as they go to poor quality schools for their high school education. Pillay 
(2010) relates the failure to access higher education to inequity in resource distribution. Students from the 'have' families find it easy to push their children to higher education than the 'have not' families. This gap widens as one move from urban to rural areas. The introduction of cost sharing in higher education, which appeared to promote access to higher education in many countries, has failed many children from low-income families (Smith, 2010). The findings are consistent with (Johnston, 2010; Van der Berg, et al..., 2017) who observes that higher education competes with vast needs at household level thereby exerting pressure on its access. University programs in Uganda are highly competitive. Due to this competition, low-income parents have no option than to send their children to schools of poor quality, where they lack access to quality teaching and facilities to enable them obtain the required points to join higher education. The findings however, disagree with (Nshemereirwe, 2016) who observes that government introduced district quota system to take care of regional balance in university admission. However, imbalances still exist in admission in universities. Most of the students who join public universities come from first-world schools, which cannot be accessed by students from low-income families. The findings further disagree with (Varghase, 2013) who establishes how countries have invested a lot in research and development activities in higher universities to promote economic growth. Much as governments provide funding for research activities, it has no relationship with how many students access universities.

The study sought to determine the relationship between financial inclusion and access to higher education. A moderate relationship was established between financial inclusion and access to higher education. The findings are consistent with (Bruhn \& Love, 2014) who observes that individuals who were previously excluded financially can now invest in education to contribute to economic growth. This category of people can now participate in business and save money for the education of their children even up to institutions of higher learning. Rich individuals with access to financial services have influence on education and income (Zins \& Weills, 2016). In view of access to higher education, individuals with higher incomes can provide for the education of their children at higher levels. The findings are further consistent with (Salmi \& Basset, 2014) who observes the equity promotion policies increase opportunities for disadvantaged students. They combine financial assistance with non-financial obstacles to increase access to education. The findings however, disagree with (Awan, et al..., 2011; Khavenson \& Wobman, 2007) who establishes a negative relationship between educational enrolment and poverty. Students from low-income families are less likely to enter an elite university compared to those from high-income families. The findings disagree with (Kyaligonza, 2017) on study loans. Study loans have been helpful in assisting students from low-income families to access higher education. However, the criteria and guidelines for obtaining this loan eliminate those from poor backgrounds, who might not be able to pay back.

\section{Conclusion}

The study brought out the relationship between financial inclusion and access to higher education. Digital financing as an aspect of financial inclusion was investigated. Digital financing eases making deposits in banks, transacting via mobile money and switching from one bank to the other. Students find it easy to deposit tuition and functional fess in the bank just as they find it easy to access money from their parents and sponsors via mobile money. It reduces students' financial resources from vulnerability to squanders, fraudsters, and conmen who are common around town. However, not many students have confidence transacting with banks on their mobile phones or digital transaction platforms. While financial inclusion makes financial services available in the economy, students, especially those from low-income families find difficulty accessing a wider range of these products, which hinders their access to higher education. In addition to coming from low-income families, the study establishes that a good number of students fail to meet admission requirements. Since students from low-income families attend high schools of low quality, they have insufficient understanding of some subjects, and thus unable to join higher education. Online registration and payment, students' decision not to join, peer influence, and rigidity of university programs; are deeply flawed to limit accessing higher education. The study establishes a moderate relationship between financial inclusion and access to higher education. Access to financial resources, study loan programs, district quota systems and cost sharing promote access to higher education. However, financial services remain accessible to rich individuals who demonstrate ability to pay. The guidelines and assessment followed to qualify for study loans and district quota systems reduce opportunities of disadvantaged students. Given the limited studies on financial inclusion and access to higher education in Uganda, this study is one of the few to focus on financial inclusion and access to higher education in eastern Uganda. The study might be useful in assessing the practical impact of access to higher education programs such as study loan, district quota system and financing research and development in Universities in Uganda.

\section{Recommendations}

The government of Uganda, through Ministry of Education and Sports, and Ministry of Finance, Planning and Economic Development should review the implementation of their policies on study loan and district quota systems. Ministry of education and Sports should always publish the lists of students admitted to higher education institutions in popular media and newspapers to allow students from low-income families gain access to these 
institutions

\section{References}

Adongo, J (2010),'Namibia”, (In: PillayPundy-Ed., Higher Education Financing in East and Southern Africa,), Somerset West: African Minds, pp. 123-152

Allen.F.,Demirguc-Kunt.A, Klapper. L \&PeriaM.S.M (2016) The Foundations of Financial Inclusion: Understanding Ownership and Use of Formal Accounts. Journal Of Financial Intermediation, 27,1-30

Anamuah-Mensa J (2014). Information Communication Technology Driven Education for Sustainable Human Development: Challenges and Prospects."Keynote Address at the $65^{\text {th }}$ Annual New Year School and Conference. Institute of Continuing and Distance Education, University of Ghana, Legon (Unpublished Material)

Atkinson, A., \& Messy F., (2013). Promoting Financial Inclusion through Financial Education: OECD/INFE Evidence, Policies and Practice. OECD Working Papers on Finance, Insurance and Private Pensions 34. Paris

Awan, M.S., Malik. N., Sarwar. H \&Waqas. M, (2011). "Impact of Education on Poverty Reduction. International Journal of Academic Research , 3(1), pp.659-664

Blackie,M,. Blackie, R., Lele,U., \&Beintema, N (2010). Capacity development and investment in agricultural research and development in Africa. Lead background paper ministerial conference on higher education in agriculture in Africa. Speke Resort Hotel, Munyonyo Kampala, Uganda

Boit,J.M\&Kipkoech, L.C (2012) Liberalization of Higher Education in Kenya: Challenges and Prospects. International Journal of Academic in Progressive Education and Development 1 (2):33-41

Bruhn, M., \& Love, I. (2014) The real impact of improved access to finance: Evidence from Mexico. The Journal of Finance, 69(3), 1347-1376

CGAP(2015). What is Digital Financial Inclusion and Why Does it Matter?10 march 2015. Available at :http://cgap.org/blog/what-digital-financial-inclusion-and-why-does-it- matter(Accessed 10 November 2017)

Chithra, N \&Selvam, M. (2013). Determinants of financial inclusion: An Empirical study on the inter-state variations in India. Retrieved from , SSRN:http://dx.doi.org/10.2139/ssrn.2296096

Demirguc-kunt, A \&Klapper, L (2012b) Financial Inclusion in Africa. The World Bank Policy Research Working paper 6088

Department: Higher Education and Training (2013a). Statistics on post-school education and training in South Africa: 2010. Pretoria: Department of Higher Education and Training.

Devarajan S, Monga C \&Zongo. T (2011) Making Higher Education Finance Work for Africa. J.Afri.Econ.. 20(3): $133-154$

Dupas.P.,Karlan. D., Robinson. J \&Ubfal. D., (2016). Banking the Unbanked? Evidence from three Countries. American Economic Journal: Applied Economics, Forthcoming

Espinosa, L., Turk,j., Taylor,M\& Chessman, H., (2019). Race and Ethnicity in Higher Education: A Status Report. Washington, D.C: American Council on Education.

Eton. M., Odubuker.P. E., Ejang. M., Bernard.P. O \& Mwosi. F (2019) Financial Accessibility and Poverty Reduction in Northern Uganda, Lango Sub-Region. International Journal of Social Science and Humanities Research ISSN 2348-3164(Online) Vol.7, Issue 2, pp (271-281) Month: April-June 2019, Available at: www.researchpublish.com

Eton.M.,Mwosi.F., Ogwel.B. P., Edaku. C \&Obote. D (2018) Financial Inclusion and Women Empowerment in Uganda. A case of Lango Sub region, Northern Uganda. Economics, Commerce and Trade Management: An International Journal (ECTIJ) Vol.2, No 1

Eton.M.,Uwonda.G., Mwosi.F., Barigye.G.,\&Ogwel.B.P., (2019).Financial Inclusion and Economic growth in Uganda. A case study of selected districts in western Uganda. International Journal of Advances in Scientific research and engineering (ijasre) Vol.5, Issue 10 October 2019, pp 138-151

G20 Summit, (2013) G20 Leaders Declaration. September, St Petersburg Russia. Available:http:www.g20.utoronto.ca/2013/2013-0906-declaration.html.(Accessed 9 November (2017)

Hanushek, E.A\&Wobman. L (2007). “The Role of education Quality for Economic Growth." World Bank Working Paper Series No. 4122.

Haus, LS (2006). Higher education marketing: Factors influencing Malaysian Students' intention to study at higher educational institutions. (Thesis, University of Malaysia, Kuala Lumpar, Malaysia)http://repository.em.edu.my/686/1/Tesis20\%20Final\%20Vrsion.pdf

Hong, H. K., \&Chae, J. E., (2011). Students Loan Policies in Korea: Evaluation, Opportunities and Challenges. Educational Research Journal. Vol.26, No, 1

Hull. G (2015), Free University education is not the route to social justice, mail and Guardian, 28 Aug,http://mg.co.za/article/2015-10-28-free-university-education-is-not-the route- to-social-justice [Accessed: 28.05.2016] 
IFC, (2017) Digital Financial Services: Challenges and opportunities for emerging market Banks. EM Compass Report, No 42, August. International Finance Corporation, World Bank.

ITU, (2016). The Digital financial services ecosystem. Technical Report. ITU Focus Group.

Jerrim, J., \&Vignoles, A , (2015). Universities access for disadvantaged children: A Comparison across countries. Higher Education, 70(6), 903-921

Johnstone, B (2010), Financing Higher Education: Who pays and other issues. http://gse.buffalo.edu/org/intHigherEdFinance/files/publications/foundation paper/(2009) Financing Higher Education.pdf [Accessed 10.05.2016]

Kelegama, S \&Tilakaratna .G (2014) Financial Inclusion, Regulation and Education in Sri Lanka. ADBI Working paper504.Tokyo: ADBI

Khavenson, T. E \&Chirkina,T.A (2018) Obrazovatelnyeperekhody v Rossii- socialnoehkonomicheskoepolozhnie semi I uspevaemost [educational Trajectories in Rusia: Socio-economic Status and Educational Outcomes] Faktyobrazovaniya [Facts on Education], (8), 2-15

Kim, E., Newton, F. B., Downey, R.G., \& Benton, S. L (2010). Personal factors impacting college student success: constructing college learning effectiveness inventory(CLEI). College Student Journal, 44(1) 112-125.

Kyaligonza. R (2017) Gaps in the Implementation of Uganda's Students Loan Scheme. MakerereJournal of Higher Education. Vol. 9(1) pp 53-64

Llanto, G (2015) Financial Inclusion, Education and Regulation in the Philippines. ADBI Working paper 541.Tokyo: ADBI

Manyika, J., Lund, S., Singer, M., White, O., \& Berry, C., (2016). Digital finance for all: Powering inclusive growth in emerging economies. USA: McKinsey Global Institute. September

Masanja,V.G\&Lwakabamba , S (2016) Liberalization of higher education in Sub-Saharan Africa. Fifth RUFORUM Biennial Regional Conference, 17-21 October 2016, Cape Town, South AfricaRUFORUM Working Document Series (ISSN 1607-9345) No. 14(2): 1-7 available on http://repository.ruforum.org

McCole, D., Culbertson, M.I., Suvedi, M., \& McNamara, P.E (2014). Addressing the challenges of Extension and Advisory Services in Uganda: The Grameen Foundation's Community knowledge worker program. Journal of International Agricultural and Extension Education, 21(1), 6-18

McMahon ,W.W (2009) Higher Education. Greater Good: The Johns Hopkins University Press, Baltimore.

Menon, M., Rodgers, Y., \& Vender, M (2011). How access to credit affects self employment: Differences by gender during India's rural banking reform. Journal of development Studies, 47(1), 48-69

Messy,F\&Monticone.C (2012), The Status of Financial Education in Africa, OECD Working Papers on Finance, Insurance and Private Pensions, No. 25, OECD Publishing.

Michelle. A.M., (2016). The effect of digital finance on financial inclusion in the banking industry in Kenya. A research project submitted in partial fulfillment of the requirements for the award of the degree of Master of Science in finance, school of business, University of Nairobi

Morgan, P \&Pontines. V (2014) Financial Stability and Financial Inclusion. ADBI Working Paper 488. Tokyo: ADBI

Moses,E., Van der Berg.S\& Rich. K (2017). "A Society Divided: How Unequal Education Quality Limits Social Mobility in South Africa," Synthesis report for the program to Support Pro-poor policy Development.

National Council for Higher Education, (2010). National Council for Higher Education: Excellence, accessibility and relevance. Retrieved from http://www.unche.or.ug/index.php

Nshemereirwe. C.V (2016) Socioeconomic Status and Access to higher education in Uganda. International journal of Educational Leadership (IJEL) Vol.7. No.1 2016

Oduro-Mensa. D (2012). Revenue Education and Mobilization Skills, Education and Training for Revenue Mobilization in Metropolitan, Municipal and District Assemblies: ACCRA: Woeli Publishing Service

OECD (Organization for Economic Cooperation and Development), (2015), Education at a Glance: $O E C D$ indicators, Paris: OECD

Oluwataya, I (2013) Banking the unbanked in rural Southwest Nigeria: Showcasing Mobile phones as mobile banks among farming households. Journal of financial services Marketing, 18, 65-73

Orondho, J.A, (2009). Elements of Education and Social Science Research Methods; Maseno Kanezja.

Pfefferman, G (2015) Higher Education in Sub Saharan Africa: Why the Neglect? http://mercatorxxi,com/merc/wp-content/uploads/2015/05/higher-education -in-sub- saharan-Africa.pdf

Pillay, P (2010), Higher Education Financing in East and Southern Africa, Somerset West: African Minds.

Rehman, A.U (2016). Academic anxiety among higher education students of India, causes and preventive measures: An exploratory study. International journal of modern social sciences, 5(2), 102-116

Roble,J (2017). Poverty fact sheet: Financial barriers to college completion. Institute for research on poverty, University of Wisconsin-Madison. https://www.irp.wisc.edu/publications/factsheets/pdf/FactSheet12Collegebarriers.pdf

Salmi, j., \& Bassett, R.M., (2014) The equity imperative in tertiary education: Promoting fairness and efficiency. 
International Review of Education, 60(3), 361-377

Smith, L (2010). Adoption of first year curriculum principles in support of an enhanced CSU student experience. Bathurst: Charles Sturt University

Ssegawa, D.E, (2012) The Management of the liberalization of higher education and it's implication to the quality of university education in Uganda. Master of Arts in Educational management Thesis, Makerere University, Uganda

The National Council of Higher Education, (2013). The State of Higher education and training in Uganda. Kampala: NCHE

Tilak, J (2011), "Financing Higher Education in Sub-Saharan Africa” Journal of development Studies, Vol.41, No.2, pp. 4-31

Tinkamanyire, D (2010, $13^{\text {th }}$ April) New Science Policy Unfair, New Vision

Trautwein, C., \& Bosse, E . (2016). The first year in Higher education-Critical requirements from the students perspective. Higher education, 73(3), 371-387.

UNESCO Institute of Statistics (UIS) (2011) Financing Education in Sub-Saharan Africa- Meeting Challenges of Expansion, Equity and Quality. http://unesdoc.unesco.org/images/0019/001921/1921e.pdf

$\begin{array}{llllll} & \text { InESCO } & \text { Institute } & \text { Statistics } & \text { (UIS) } & \text { (2014) }\end{array}$ www.uis.unesco.org/Datacentre/pages/countryprofile. aspx ?recgioncode $=40500 \& \operatorname{code}=\mathrm{G}$ BR.Accessed on $2^{\text {nd }}$ November 2015

UNESCO UIS, (2017) Educational attainment in Columbia. Retrieved from http://uis.unesco.org/country//co

Wamboga-Mugirya, P (2005, $22^{\text {nd }}$ February). Science education gets double boost in Uganda. New Vision

Wedekind, V. (2013). Cut them off at the pass! A discussion document for Umalusi on the NSC pass mark. Pretoria: Umalusi

World Bank, (2013a) Financial inclusion Strategies Database.

World Bank, (2014), Global Financial Development Report. Financial Inclusion. Washington, DC

World Bank, (2018a). "Learning to Realize Education's Promise”, World Development Report 2018, Washington $\mathrm{DC}$

Yizengaw T (2008) Challenges Facing Higher Education in Africa and Lessons from Experience: A synthesis report for the Africa-US Higher Education Initiative

Zins, A., \& Weill, L (2016). The determinants of financial inclusion in Africa. Review of development finance, 6(1), 46-57

Zwick, R \&Himelfarb ,I (2011) The effect of High School Socioeconomic Status on the predictive validity of SAT scores and High School Grade-Point Average. Journal of Educational Measurement,Vol.48,No.2, pp,101121 